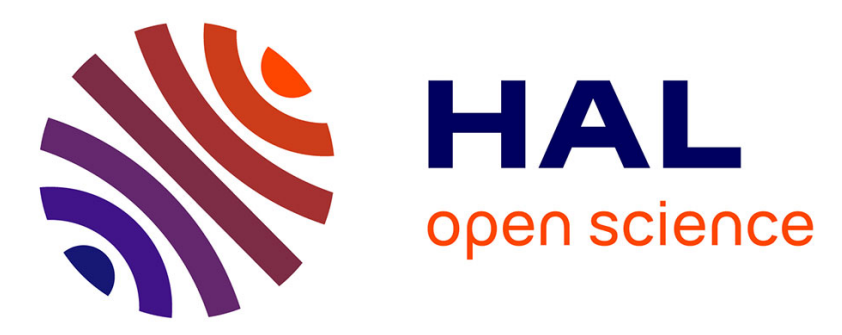

\title{
Interaction of magnetic nanoparticles with U87MG cells studied by synchrotron radiation $\mathrm{X}$-ray fluorescence techniques
}

\author{
Alessandra Gianoncelli, Patrick Marmorato, Jessica Ponti, Lorella Pascolo, \\ Burkhard Kaulich, Chiara Uboldi, François Rossi, D Makovec, M Kiskinova, \\ Giacomo Ceccone
}

\section{To cite this version:}

Alessandra Gianoncelli, Patrick Marmorato, Jessica Ponti, Lorella Pascolo, Burkhard Kaulich, et al.. Interaction of magnetic nanoparticles with U87MG cells studied by synchrotron radiation X-ray fluorescence techniques. X-Ray Spectrometry, 2013, 42 (4), pp.316-320. 10.1002/xrs.2475 . hal02353950

\author{
HAL Id: hal-02353950 \\ https://hal.science/hal-02353950
}

Submitted on 7 Nov 2019

HAL is a multi-disciplinary open access archive for the deposit and dissemination of scientific research documents, whether they are published or not. The documents may come from teaching and research institutions in France or abroad, or from public or private research centers.
L'archive ouverte pluridisciplinaire $\mathbf{H A L}$, est destinée au dépôt et à la diffusion de documents scientifiques de niveau recherche, publiés ou non, émanant des établissements d'enseignement et de recherche français ou étrangers, des laboratoires publics ou privés. 


\title{
Interaction of magnetic nanoparticles with U87MG cells studied by synchrotron radiation $X$-ray fluorescence techniques
}

\author{
A. Gianoncelli, ${ }^{\text {a }}$ P. Marmorato, ${ }^{\text {b }}$ J. Ponti, ${ }^{\text {b }}$ L. Pascolo, ${ }^{\text {c }}$ B. Kaulich, ${ }^{\text {a,d }}$ \\ C. Uboldi, ${ }^{b}$ F. Rossi, ${ }^{b}$ D. Makovec, ${ }^{\text {e M. Kiskinova }}{ }^{a}$ and G. Ceccone ${ }^{b *}$
}

\begin{abstract}
Synchrotron radiation (SR) X-ray microscopy combined with X-ray fluorescence (XRF) microspectroscopy provides unique information that have pushed the frontiers of biological research, particularly when investigating intracellular mechanisms. This work reports an SR-XRF microspectroscopy investigation on the distribution and the potential toxicity of $\mathrm{Fe}_{2} \mathrm{O}_{3}$ and $\mathrm{CoFe}_{2} \mathrm{O}_{4}$ nanoparticles (NPs) in U87MG glioblastoma-astrocytoma cells. The U87MG cells exposed to NPs concentrations ranging from 5 to $250 \mu \mathrm{g} / \mathrm{ml}$ for $24 \mathrm{~h}$ were analyzed in order to monitor both morphological and chemical changes. The SR-XRF maps complemented with XRM absorption and phase contrast images have revealed different intracellular distribution patterns for the two nanoparticles types allowing different mechanism of toxicity to be deduced. Copyright $\odot 2013$ John Wiley \& Sons, Ltd.
\end{abstract}

\section{Introduction}

The advent of ultrabright and tunable synchrotron light sources has lead to the development of high resolution X-ray imaging combined with micro X-ray fluorescence (XRF) elemental mapping, opening the unique opportunity for morphology and chemical imaging at submicron level, relevant for biological research. The characterization based on these methods, correlated to conventional approaches, becomes very attractive for investigating the biological effect of nanomaterials at single cell level. ${ }^{[1]}$

Nanotechnology has a great potential to solve present and future challenges in several fields such as energy, material, environment, and medicine. After more than 2 decades of basic and applied research, nanotechnologies are reaching the commercial use and the number of producers offering basic nanomaterials is growing fast. ${ }^{[2,3]}$ In fact, nowadays more than 1300 products containing nanomaterials (e.g. tires, sporting goods and clothing, sunscreens, cosmetics, food and electronics) are on the market. ${ }^{[4]}$

Notably, an increasing number of nanoproducts is considered in biomedicine as diagnostic, imaging, and drug delivery tools. ${ }^{[5-7]}$ For example, Ag NPs and ZnO NPs are added as antibacterial in several cosmetics, sunscreens, ${ }^{[8]}$ and medical products, ${ }^{\left[{ }^{[9]}\right.}$ whereas $\mathrm{TiO}_{2}$ and $\mathrm{SiO}_{2} \mathrm{NPs}$ are used as food additives as well. ${ }^{[10]}$ Furthermore, magnetic nanoparticles (MNPs), such as ferrites $\left(\mathrm{Fe}_{3} \mathrm{O}_{4}\right)$ and cobalt ferrites $\left(\mathrm{CoFe}_{2} \mathrm{O}_{4}\right)$, have found possible applications in biomedicine as drug carriers, as hyperthermia treatments in cancer therapy, and as magnetic resonance imaging contrast enhancement ${ }^{[11]}$ and have also acquired importance in imaging relevant to cancer and diabetes diseases. ${ }^{[12]}$ In the field of tissue engineering, MNPs have already been considered for many applications including cellular labeling, cell sorting and monitoring, targeted in vivo therapeutic delivery, stem cell replacement therapy, and welding tissue surfaces. ${ }^{[13]}$ For instance, incorporating superparamagnetic NPs into mesenchymal stem cells for the regeneration of tissue damage in the central nervous system has enabled imaging and monitoring of cellular migration by external magnetic fields to the wound site and helped optimizing the number of cells needed for tissue regeneration and monitoring possible side effects. ${ }^{[14]}$ Some superparamagnetic nanoparticles have been approved for imaging and therapeutic applications in humans, for example, Feridex IV ${ }^{\circledR}$ and Combidex ${ }^{\circledR}$ (Advanced Magnetics Inc., Lexington, MA, USA) ${ }^{[5-7]}$ and several other superparamagnetic nanoparticles are undergoing phases I and II clinical trials. ${ }^{[15]}$

Although nanomaterials are key factors in nanotechnology innovations, their presence in commercial products raise concerns about possible adverse effects on environment, human health, and society (NanoEHS). In fact, even if the composition of nanomaterials is not considered as toxic, they may pose serious safety problems due to unpredicted interactions resulting from physicochemical properties controlled by their specific size, structure, and surface chemistry. However, despite the large amount of data reviewing the potential toxicity of nanoparticles, the evaluation and mechanisms of nanomaterials toxicity (nanotoxicity) are still poorly understood. In fact, there are conflicting results about toxicity of nanomaterials. For instance, $\mathrm{SiO}_{2} \mathrm{NPs}$ are found to induce cytotoxicity in some cell lines ${ }^{[16]}$ but not in others, ${ }^{[17,18]}$ whereas current studies of toxicity of carbon nanotubes and $\mathrm{TiO}_{2}$ have reported controversial results. ${ }^{[19]}$

Among the promising detection methods, synchrotron radiation XRF (SR-XRF) has already demonstrated its potential in biomedical research for exploring, among others, neurodegenerative disorders. ${ }^{[20-23]}$ The application of SR-XRF with soft X-rays ${ }^{[24]}$

\footnotetext{
* Correspondence to: G. Ceccone, European Commission, Joint Research Centre, IHCP, Ispra (VA), Italy. E-mail: giacomo.ceccone@jrc.ec.europa.eu

a ELETTRA Sincrotrone Trieste, Trieste, Italy
}

b European Commission, Joint Research Centre, IHCP, Ispra (VA), Italy

c Institute for Maternal and Child Health, IRCCS Burlo Garofolo, Trieste, Italy

d Diamond Light Source, Didcot, Oxfordshire, OX11 ODE, UK

e Jozef Stefan Institute, Jamova Cesta 39, Ljublijana SI-1000, Slovenia 
has recently provided access to light elements, which are major constituents of the living matter and this set-up is developed and implemented for the first time in the TwinMic microscope operated at Elettra laboratory (Trieste, Italy). Using this set-up, which combines submicron soft X-ray microscopy with low energy XRF (LE-XRF) microspectroscopy, we recently investigated the effect $\mathrm{CoFe}_{2} \mathrm{O}_{4}$ nanoparticles in mouse fibroblasts (Balb/3 T3 cells), showing that the accumulation of these nanoparticles can induce metabolic change. ${ }^{[25]}$ In the present study, we investigated the effect of two iron-based nanoparticles in a new cell line monitoring morphological and chemical changes in the cells using the complementary X-ray imaging and LE-XRF capabilities of TwinMic beamline at Elettra Synchrotron in Trieste. ${ }^{[26]}$ In particular, we have investigated the interaction of ferrites $\left(\mathrm{Fe}_{2} \mathrm{O}_{3}\right.$, maghemite), and cobalt ferrites $\left(\mathrm{CoFe}_{2} \mathrm{O}_{4}\right) \mathrm{NPs}$ with U87MG human glioblastomaastrocytoma cells.

\section{Experimental}

Ferrites $\left(\mathrm{Fe}_{2} \mathrm{O}_{3}\right.$, maghemite) nanoparticles were synthesized in Josef Stefan Institute (Lubljana, Slovenia) using the wellknown co-precipitation of $\mathrm{Fe}^{2+}$ and $\mathrm{Fe}^{3+}$ salts using $\mathrm{NH}_{4} \mathrm{OH}$ in the presence of ricinoleic acid to obtain hydrophobic NPs surface. ${ }^{[27,28]}$ Thermogravimetric analyses showed that the asprepared suspension consisted of $29 \mathrm{wt} \%$ iron-oxide, $12 \mathrm{wt} \%$ ricinoleic acid, and 59wt\% methyl methacrylate (PMMA), whereas the X-ray diffraction data showed that maghemite NPs were obtained. The presence of the PMMA onto the nanoparticles was also confirmed by X-ray photoelectron spectroscopy analysis (data not shown).

Dynamic light scattering (DLS) measurements were carried out on $1 \mathrm{ml}$ sample volume with the Zetasizer Nano Zs (Malvern Instruments, UK), following the measurement protocols indicated by ISO 13321:1996. Three measurements instead of the recommended six were performed after data quality assessment showing comparable results. The results of three measurements for each sample were averaged by the Zetasizer software.

The $\mathrm{CoFe}_{2} \mathrm{O}_{4} \mathrm{NPs}$ were supplied by Colorobbia S.p.A. (Italy) as suspension in $100 \%$ diethylene glycol (DEG). NPs were synthesized using the polyol method: cobalt acetate and iron acetate were solubilized in DEG at $110^{\circ} \mathrm{C}$ for $1 \mathrm{~h}$, and then the solution was heated to $180^{\circ} \mathrm{C}$. After $3 \mathrm{~h}$, the product was air cooled to room temperature and then stored. ${ }^{[29]}$ Cobalt concentration of $7 \mu \mathrm{g} / \mathrm{mL}$ was measured by inductively coupled plasma mass spectrometry (PerkinElmer, ELAN DRC II SCIEXTM, Canada).

U87MG human glioblastoma-astrocytoma cells (ATCC number HTB-14) were prepared from deep-frozen stock vials, kept in a subconfluent state and maintained in complete culture medium (Modified Eagle Medium low glucose, 10\%(v/v) fetal bovine serum (FBS) Australian origin, $1 \%(\mathrm{v} / \mathrm{v})$ penicillin/streptomycin, Invitrogen, Milan, Italy) under standard cell culture conditions $\left(37^{\circ} \mathrm{C}, 5 \% \mathrm{CO}\right.$, and $95 \%$ humidity, HERAEUS incubator, Germany).

The potential toxicity of $\mathrm{Fe}_{2} \mathrm{O}_{3}$ and $\mathrm{CoFe}_{2} \mathrm{O}_{4}$ NPs was evaluated by trypan blue exclusion dye test. The cytotoxicity of nanoparticles was tested after $24 \mathrm{~h}$ of exposure at concentrations ranging from 1 to $235 \mu \mathrm{g} / \mathrm{ml} .7 \times 10^{4}$ U87MG cells were cultured overnight into 24 well-plates and then incubated for $24 \mathrm{~h}$ with nanoparticles. At the end of the exposure time, cells were washed with phosphate buffer solution (PBS; Invitrogen, Italy), trypsinized and counted.
For the SR-XRF analysis, the cells were cultured on silicon nitride membrane (Silson Ltd, Northampton, UK) contained in six wells plate (Corning, Costar) at the density of $10^{5}$ cells/well in $3 \mathrm{ml}$ of complete culture medium. After $24 \mathrm{~h}$, the medium was changed and cells were exposed to $\mathrm{CoFe}_{2} \mathrm{O}_{4}$ or maghemite nanoparticles (concentrations $5-50 \mu \mathrm{g} / \mathrm{ml}$ range). After $24 \mathrm{~h}$, samples were washed twice with PBS and fixed with $4 \%(\mathrm{v} / \mathrm{v})$ of formaldehyde solution (Sigma, Italy) in PBS buffer.

The TwinMic instrument used for the present investigation works in the $0.4-2.2 \mathrm{keV}$ energy range. ${ }^{[24,30]}$ Soft X-ray microscopy can be performed both in full-field imaging and scanning transmission (STXM) modes. ${ }^{[31]}$ The data were acquired using the STXM mode, where the X-ray beam can be focused down to sub- $\mu \mathrm{m}$ spot size by zone plate diffractive optics and the specimen is raster-scanned across the X-ray probe for obtaining 2D images. The X-ray absorption and phase contrast images of transmitted X-rays were recorded by an Andor-Technology CCD camera providing simultaneously absorption and phase information. ${ }^{31}$ Simultaneous monitoring of the emitted fluorescence signal using eight silicon drift detectors distributed circularly in front of the sample provide the elemental maps covering $\mathrm{K}$ or $\mathrm{L}$ fluorescence emission of elements in the $150-2000 \mathrm{eV}$ range (From $\mathrm{B}$ to $\mathrm{P}$ and metals as $\mathrm{Mg}, \mathrm{Fe}, \mathrm{Mn}, \mathrm{Cu}$, and $\mathrm{Zn}){ }^{[32]}$ This simultaneous X-ray transmission and LE-XRF mapping allows direct correlation of the sample morphology to elemental composition.

The present experiments were carried out with photon energy $1.1 \mathrm{keV}$ and spot size of $650 \mathrm{~nm}$ for XRF mapping, which was a good compromise for getting a sufficient fluorescence signal with acceptable spatial resolution. The elemental map was acquired in hdf5 format and then analyzed by the multiplatform program (PyMCA) developed by V. Sole and co-workers. ${ }^{[33]}$

\section{Results and discussion}

Table 1 reports the results of DLS analysis of the $\mathrm{Fe}_{2} \mathrm{O}_{3}$ and $\mathrm{CoFe}_{2} \mathrm{O}_{4}$ in different media. The DLS data indicate an average hydrodynamic diameter of $111.6 \pm 5.9$ in MilliQ water and $35.6 \pm 1.1 \mathrm{~nm}$ in the stock solution for $\mathrm{Fe}_{2} \mathrm{O}_{3}$ and $\mathrm{CoFe}_{2} \mathrm{O}_{4}$, respectively. The average diameter increases when the NPs are in contact with different biological media. In particular, the average diameter of $\mathrm{Fe}_{2} \mathrm{O}_{3}$ increases to $150.5 \pm 14.2 \mathrm{~nm}$ in cell culture media, whereas in the case of $\mathrm{CoFe}_{2} \mathrm{O}_{4}$, the average diameter increases to about $560 \mathrm{~nm}$ (Table 1). These results indicate the tendency to agglomeration of the $\mathrm{CoFe}_{2} \mathrm{O}_{4} \mathrm{NPs}$ when in contact with the culture medium rich in proteins because the hydrophilic surface of $\mathrm{CoFe}_{2} \mathrm{O}_{4}$ NPs nanoparticles is directly exposed to the proteins present in the culture medium. On the other hand, the $\mathrm{Fe}_{2} \mathrm{O}_{3}$ NPs are covered with PMMA that makes them more

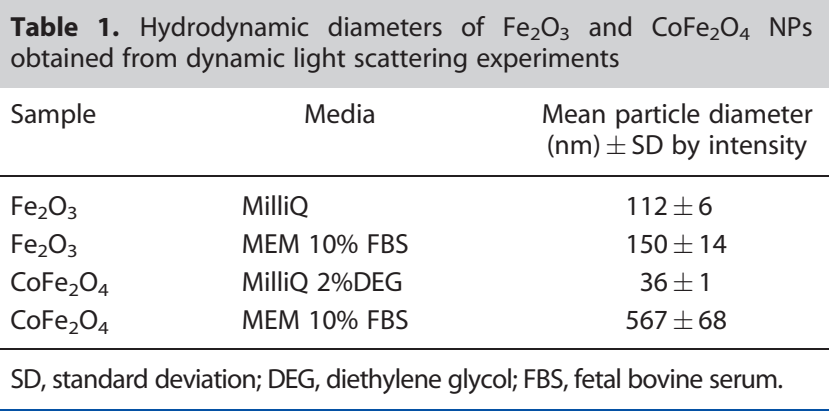


hydrophobic and prevent the agglomeration but not the protein corona formation.

The Trypan dye exclusion test determined that U87MG cells maintain a viability from $100 \%$ to $80 \%$ when exposed from 10 to $235 \mu \mathrm{g} / \mathrm{ml}$ of $\mathrm{CoFe}_{2} \mathrm{O}_{4} \mathrm{NPs}$. Differently, U87MG exposed to $5 \mu \mathrm{g} / \mathrm{ml}$ of $\mathrm{Fe}_{2} \mathrm{O}_{3} \mathrm{NPs}$ have shown a viability of about $30 \%$, which is stable up to $75 \mu \mathrm{g} / \mathrm{ml}$. A total of 5 and $50 \mu \mathrm{g} / \mathrm{ml}$ are the test concentrations chosen for XRF analyses and to compare morphological and chemical changes.

The $\mathrm{X}$-ray absorption and phase contrast images together with the $\mathrm{C}, \mathrm{Fe}, \mathrm{O}$, and $\mathrm{Na}$ elemental maps of a control U87MG cell are shown in Fig 1. At the photon energy used (1.1 keV), the differential phase contrast image is better than the absorption one in defining the morphology of the cell, enhancing the cell borders, and it adds a three-dimensional perception of the nuclear structure. On the other hand, the denser nucleoli inside the nucleus are appreciable in both the images. The maps of the endogenous macroelements $\mathrm{C}, \mathrm{O}$, and $\mathrm{Na}$ confirm the cell shape and density of the intracellular structures. The Fe map shows only a few small spots where the Fe is slightly higher than in the background. This indicates that the contribution to the Fe signal due to the Fe present in the cell is negligible.

Figures 2 and 3 together with Figs. 4 and 5 depict $X$-ray absorption and phase contrast images together with the $\mathrm{C}, \mathrm{Fe}, \mathrm{O}$, and $\mathrm{Na}$ elemental maps of U87MG cells exposed for $24 \mathrm{~h}$ at two different concentrations ( 5 and $50 \mu \mathrm{g} / \mathrm{ml}$ ) of $\mathrm{Fe}_{2} \mathrm{O}_{3} \mathrm{NPs}$ and $\mathrm{CoFe}_{2} \mathrm{O}_{4} \mathrm{NPs}$ (58 and $235 \mu \mathrm{g} / \mathrm{ml}$ ), respectively. The limits of the cell structures and the presence of NPs, highly concentrated inside the cells,
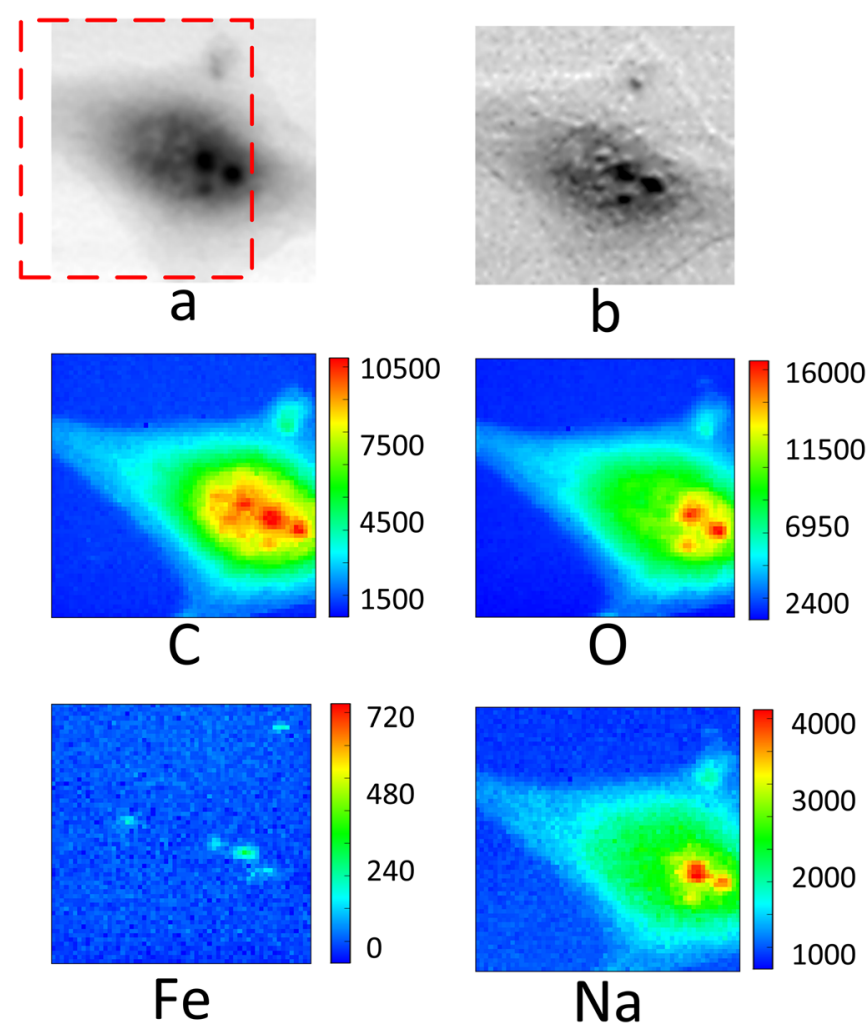

Figure 1. Absorption (a) and differential phase contrast (b) images of a U87MG control (not exposed to nanoparticles) cell $(40 \mu \mathrm{m} \times 40 \mu \mathrm{m}$, $20 \mathrm{~ms}$ dwell time). Low energy XRF maps of $\mathrm{C}, \mathrm{Na}, \mathrm{O}$, and Fe acquired on the area shown in panel a. The maps were collected on a $40 \mu \mathrm{m} \times 40 \mu \mathrm{m}$ area in an overall $60 \times 60$ pixel scan with $15 \mathrm{~s} /$ pixel acquisition time and spatial resolution of about $650 \mathrm{~nm}$.
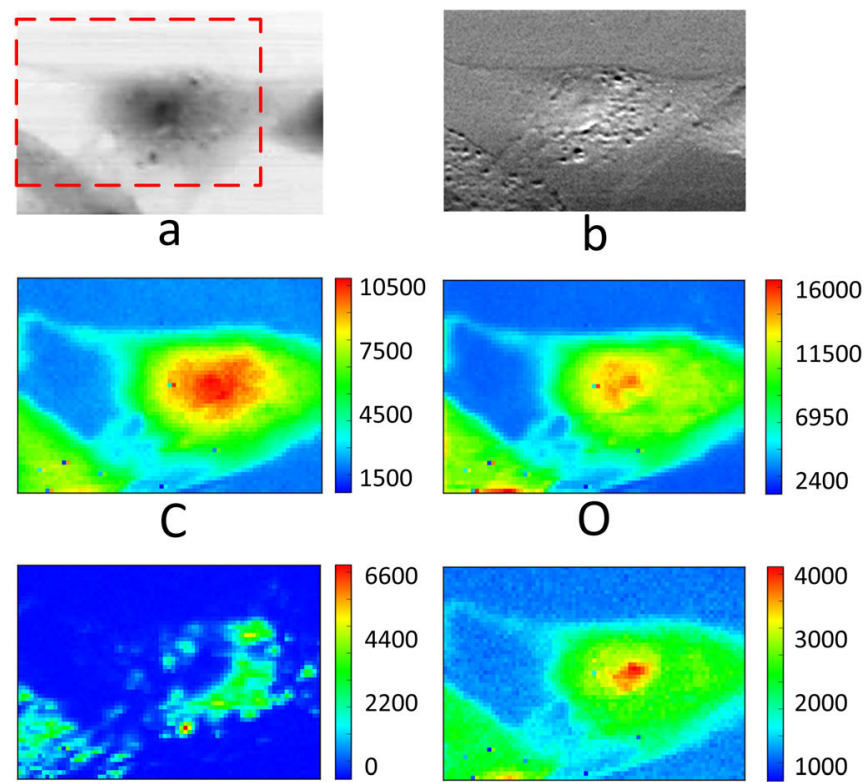

$\mathrm{Fe}$
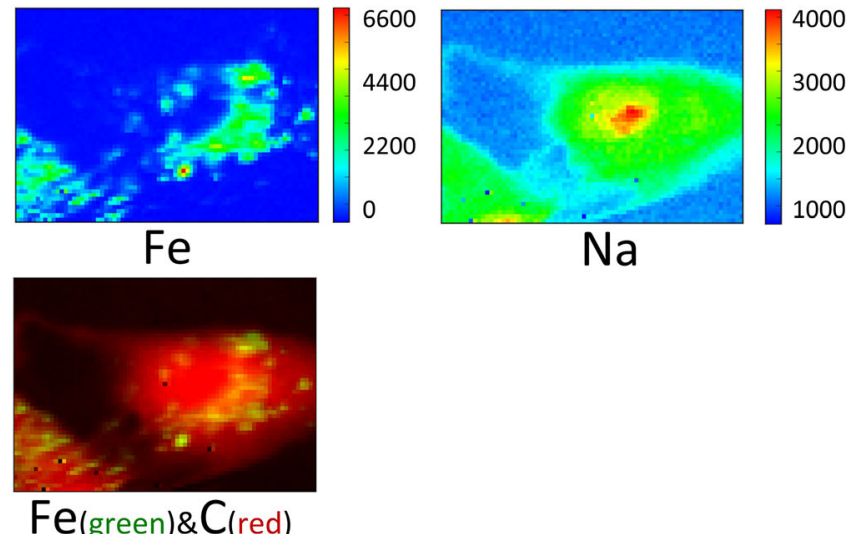

$\mathrm{Na}$

Figure 2. Absorption image (a), differential phase contrast (b) image, and XRF maps of $\mathrm{C}, \mathrm{O}, \mathrm{Co}, \mathrm{Fe}$, and $\mathrm{Na}$, with co-localization of $\mathrm{Fe}$ and $\mathrm{C}$, all acquired at $1.1 \mathrm{keV}$ on a U87MG cell exposed to $5 \mu \mathrm{g} / \mathrm{ml} \mathrm{Fe}_{2} \mathrm{O}_{3} \mathrm{NPs}$. The object field was $50 \times 36 \mathrm{~mm}^{2}$. The acquisition time of the $75 \times 54$ pixels XRF maps was $12 \mathrm{~s} /$ pixel.

are clearly visible both in the absorption and differential phase contrast images. The localization is finally confirmed by Fe (and Co) maps. A clear increase of $O$ content is also evidenced in correspondence of the NPs. At low NPs concentrations, the Fe maps indicate a distribution of both iron-based NPs maximal in the perinuclear region. As clearly shown in the Fe map in Fig. 2 and in the Fe and Co maps in Fig. 4, the NPs are asymmetrically localized in the Golgi-like region or in the endoplasmic reticulum. However, at $50 \mu \mathrm{g} / \mathrm{ml}$, the $\mathrm{Fe}_{2} \mathrm{O}_{3}$ accumulation induces stress in the cells: the nucleus in the respective Fig. 3 (panels a and b) is almost contracted and the NPs are broadly distributed or aggregated inside the cell. This, in addition to the viability data, indicates an increasing cellular stress in the presence of NPs concentrations above $5 \mu \mathrm{g} / \mathrm{ml}$. It should be also noticed that the cells exposed to $\mathrm{CoFe}_{2} \mathrm{O}_{4}$ NPs show a different morphology compared with both the control and the cells exposed to the maghemites. In fact, both phase contrast and absorption images show the presence of a white corona around the nucleus (Figs. 4 and 5) that is absent in the cells exposed to $\mathrm{Fe}_{2} \mathrm{O}_{3}$ NPs (Figs. 2 and 3) and in the control (Fig. 1). This may indicate a different type of interaction between cells and nanoparticles, different pathways of internalization and toxicity mechanisms. In fact, the difference in size of the nanoparticles when in contact with the culture medium might indicate a different uptake level of the ferrites compared with the $\mathrm{CoFe}_{2} \mathrm{O}_{4} \mathrm{NPs}$. In the latter case, the presence of large agglomerates will probably reduce the number of nanoparticles internalized by the cells. However, at this stage, 


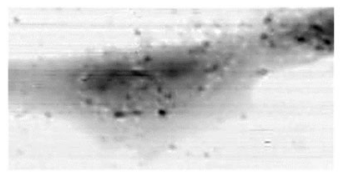

a

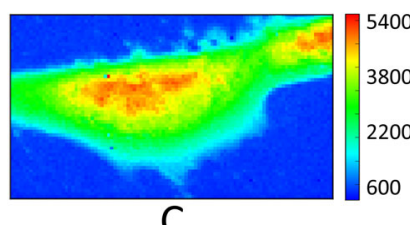

C

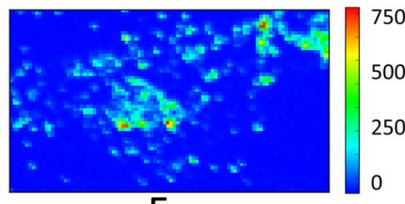

$\mathrm{Fe}$

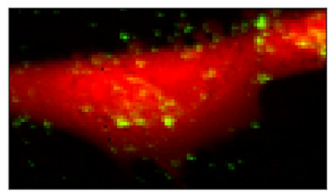

$\mathrm{Fe}\left(\right.$ green)\& $\mathrm{C}_{(\text {red })}$

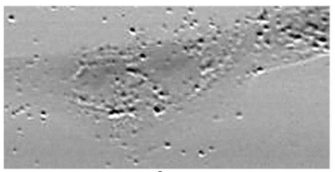

b
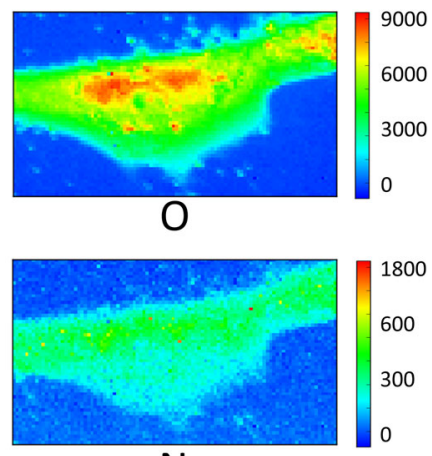

$\mathrm{Na}$
Figure 3. Absorption image (a), differential phase contrast (b) image, and XRF maps of $\mathrm{C}, \mathrm{O}, \mathrm{Co}, \mathrm{Fe}$, and $\mathrm{Na}$, with co-localization of $\mathrm{Fe}$ and $\mathrm{C}$, all acquired at $1.1 \mathrm{keV}$ on a U87MG cell exposed to $50 \mu \mathrm{g} / \mathrm{ml} \mathrm{Fe}_{2} \mathrm{O}_{3} \mathrm{NPs}$. The object field was $66 \times 40 \mu \mathrm{m}^{2}$. The acquisition time of the $100 \times 60$ pixels XRF maps was $9 \mathrm{~s} /$ pixel.

it is difficult to make a quantitative comparison of the two nanoparticles and further studies are needed to clarify this point. Moreover, it is also difficult to draw a conclusion only on the base of DLS measurements because it is well known that DLS data could strongly be influenced by the presence of a few large particles, aggregates or agglomerates that will mask the contribution of small nanoparticles. Moreover, the release of $\mathrm{Co}$ in the culture media from the $\mathrm{CoFe}_{2} \mathrm{O}_{4} \mathrm{NPs}$ that are not covered by polymers further complicate the system, making difficult to compare the behavior of the nanoparticles. The most interesting result from the comparison of the elemental maps is the clearly increase of $\mathrm{C}$ content in the perinuclear region in the presence of $\mathrm{CoFe}_{2} \mathrm{O}_{4} \mathrm{NPs}$, partially co-localized with $\mathrm{Fe}$ (see the $\mathrm{C}$ and $\mathrm{Fe}$ colocalization maps). This interesting result is in agreement with our previous data indicating that the presence of $\mathrm{CoFe}_{2} \mathrm{O}_{4}$ in Balb/3 33 fibroblasts causes the accumulations of lipid droplets inside the cells, the effect being NPs concentration-dependent. ${ }^{[25]}$ It is not surprising that the astrocytoma-derived cells show similar cell response, whereas the lack of a comparable metabolic change in the presence of $\mathrm{Fe}_{2} \mathrm{O}_{3} \mathrm{NPs}$ is a real novel result. The uptake of Fe-based NPs by a cell and its accumulation, particularly at high doses, may influence the cell electronic and/or ionic transport chains. For instance, a recent study using XANES technique has shown that the redox state of $\mathrm{Fe}$ in iron-oxide nanoparticles can induce oxidative stress in Escherichia Coli bacteria. ${ }^{[3]}$ Thus, it is not surprising that $50 \mu \mathrm{g} / \mathrm{ml}$ causes pre-apoptotic conditions as resulting from the nuclear contraction in Fig. $3(a, b)$. On the other hand, it is highly plausible that a different availability of Fe to interact with cell structure in the presence or absence of Co in the NPs could be the reason for different toxicological
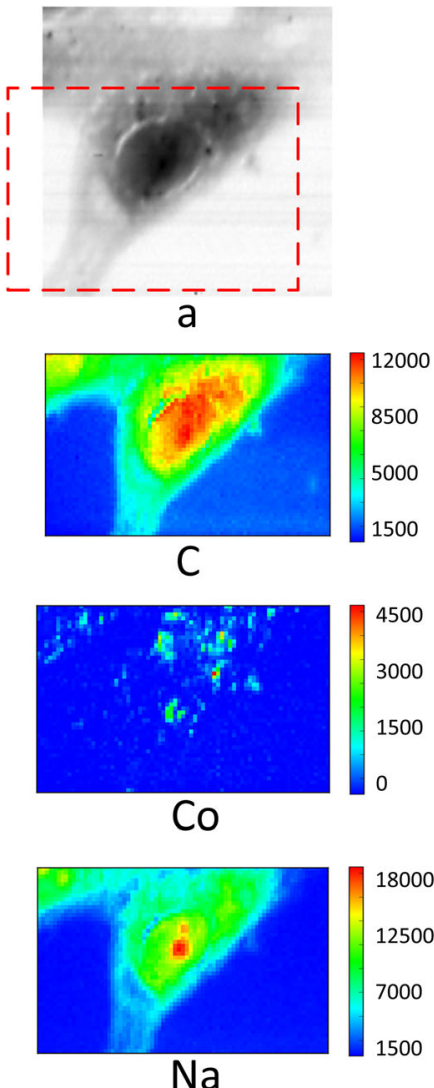

$\mathrm{Na}$

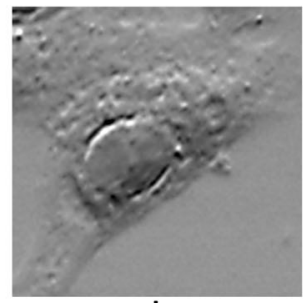

b
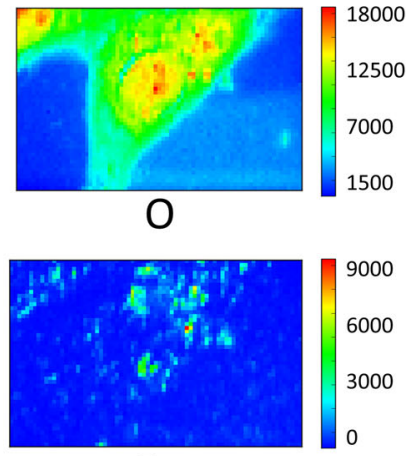

$\mathrm{Fe}$

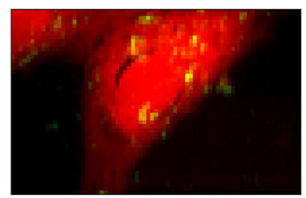

$\mathrm{Fe}$ (green)\& $\mathrm{C}_{\text {(red) }}$
Figure 4. Absorption (a) and phase contrast (b) images of a U87MG cell exposed to $58.75 \mu \mathrm{g} / \mathrm{ml}$ concentration of $\mathrm{CoFe}_{2} \mathrm{O}_{4} \mathrm{NPs}\left(40 \times 40 \mu \mathrm{m}^{2}\right.$ size, $40 \mathrm{~ms}$ dwell time, $285 \mathrm{~nm}$ spot size). The other panels show the XRF maps of $\mathrm{C}, \mathrm{O}, \mathrm{Fe}, \mathrm{Co}$, and $\mathrm{Na}\left(40 \times 40 \mu \mathrm{m}^{2}\right.$ size, $60 \times 60$ pixels, $650 \mathrm{~nm}$ spot size $)$ together with the co-localization of $\mathrm{Fe}$ and $\mathrm{C}$, among the area indicated in red in panel a. All the images were acquired at $1.1 \mathrm{keV}$ and $15 \mathrm{~s} /$ pixel was used for the XRF elemental maps.

pathways in astrocytoma-derived U87MG cells. In fact, the U87MG cells exposed to $\mathrm{CoFe}_{2} \mathrm{O}_{4} \mathrm{NPs}$ show different peculiar features. The absorption and phase contrast images [Figs. 4(a and b) and $5(a$ and $b)$ ] evidence the presence of a less absorbing circle delineating the cell nucleus. Both the white corona around the nucleus and some morphological changes of the cells (enlarged cell body and pale plasma membrane borders), suggest that the cell is under stress. At concentrations $\geq 60 \mu \mathrm{g} / \mathrm{ml}$, the presence of bright vesicles in the cytoplasm becomes more evident. As explained in a previous publication ${ }^{[25]}$, the vesicles appear to be lipid droplet organelles and their number increases when the cells are exposed to the NPs. Moreover, in the same work, we have shown that in fibroblast cells exposed to $\mathrm{CoFe}_{2} \mathrm{O}_{4} \mathrm{NPs}$ at concentrations below $58 \mu \mathrm{g} / \mathrm{ml}$, Co and Fe are localized in cytosol, indicating that the NPs are preferentially localized in the perinuclear region. On the other hand, at higher concentrations $(\geq 117 \mu \mathrm{g} / \mathrm{ml})$, $\mathrm{Fe}$ and $\mathrm{Co}$ are also present in the nuclear region of the cell, with sensible accumulation of $\mathrm{Co}$. A co-localization of $\mathrm{P}, \mathrm{Ca}$, and $\mathrm{Fe}$ at high concentration has also been observed indicating intracellular sequestration mechanisms as a response or in an attempt to reduce the nanoparticles toxic effects.

Nucleoli seem to be better defined in unexposed control U87MG cells (Fig. 1) than in the cells incubated in the presence of maghemite NPs (Figs. 2 and 3), highlighting once more the stress induced by the interaction of U87MG cells with NPs. 

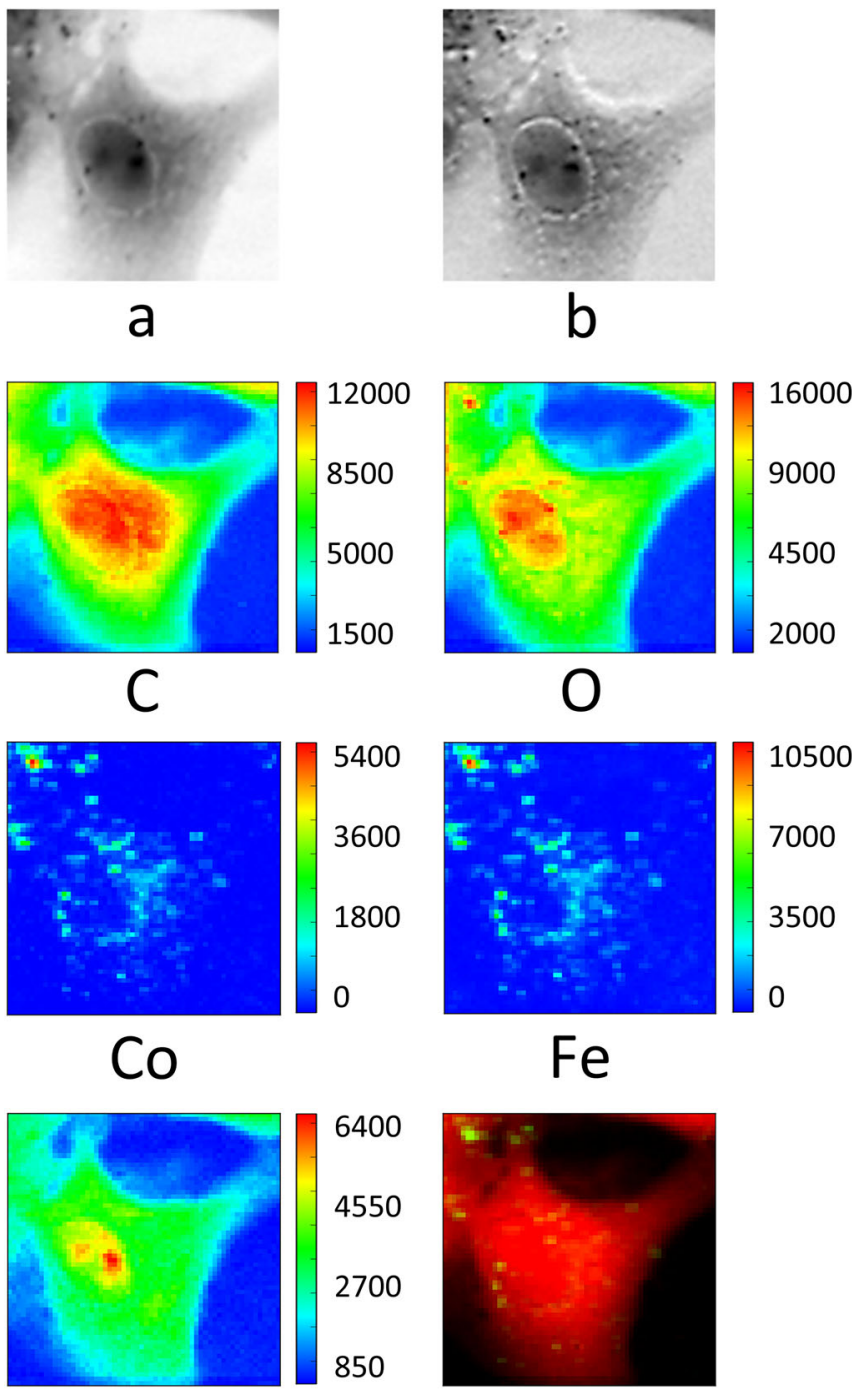

6400

4550

2700

850

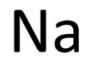

\section{Fe}
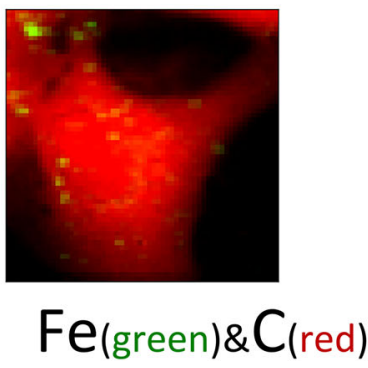

Figure 5. Absorption (a) and phase contrast (b) images of a U87 cell exposed to $235 \mu \mathrm{g} / \mathrm{ml}$ concentration of $\mathrm{CoFe}_{2} \mathrm{O}_{4} \mathrm{NPs}\left(40 \times 40 \mu \mathrm{m}^{2}\right.$ size, $40 \mathrm{~ms}$ dwell time, $285 \mathrm{~nm}$ spot size). The other panels show the elemental distribution of $\mathrm{C}, \mathrm{O}, \mathrm{Fe}, \mathrm{Co}$, and $\mathrm{Na}\left(40 \times 40 \mu \mathrm{m}^{2}\right.$ size, $40 \times 40$ pixel, $650 \mathrm{~nm}$ spot size) and the co-localization of Fe and C among the area of panels $\mathrm{a}$ and $\mathrm{b}$. All the images were acquired at $1.1 \mathrm{keV}$ and $15 \mathrm{~s} / \mathrm{pixel}$ was used for the XRF elemental maps.

\section{Conclusions}

Soft X-ray microscopy coupled with LE-XRF has proven to be a valuable and powerful tool for investigating biochemical processes at subcellular level. The combination of morphological and elemental information can provide useful insights on complex processes in biological matter occurring at the submicron length scales.

Even though the spatial resolution used in this investigation did not allow detecting single NPs, NPs clusters were easily visible through absorption, phase contrast, and XRF imaging. As discussed earlier, the present study has allowed extrapolating new insight in the interaction between cells and NPs. Further investigations at higher energies, allowing the detection of heavier elements such as $\mathrm{P}, \mathrm{S}$, and $\mathrm{Ca}$, which are important constituents of the cells, are planned and they would help in evaluating the behavior of cells in the presence of NPs.

\section{Acknowledgements}

This work has been carried out within the 'Nanobiosciences' Joint Research Center action. The European Commission and Friuli Venezia Giulia Region (Nanotox 0060 grant 2009) are gratefully acknowledged for the financial support. The authors would like to thank G. Baldi and co-workers for providing the cobalt ferrites nanoparticles. The authors are also grateful to Dr. G. Giudetti for the DLS measurements.

\section{References}

[1] A. Ide-Ektesssabi, Applications of Synchrotron Radiation: Micro Beams in Cell Microbiology and Medicine, Springer Verlag, Berlin, D, 2007.

[2] www.sigmaaldrich.com/materials-science/nanomaterials.html (accessed March 2012).

[3] Cheaptubes.com, the source for Carbon Nanotubes, http://www. cheaptubesinc.com (accessed March 2012).

[4] (http://www.nanotechproject.org/inventories/consumer/updates/).

[5] K. K. Jain. Clin. Chim. Acta 2005, 358, 37.

[6] D. A. Giljohann, D. S. Seferos, W. L. Daniel, M. D. Massich, P. C. Patel, C. A. Mirkin. Angew. Chem. Int. Ed. 2010, 49, 3280.

[7] Roadmaps in Nanomedicine towards 2020, Expert report, Nanomedicine European Technology Platform, 2009.

[8] G. J. Noynek, J. Lademann, C. Ribaud, M. S. Roberts. Crit. Rev. Toxicol. 2007, 37(3), 251.

[9] N. Sanvicens, M. Marco. Trends Biotechnol. 2008, 26(8), 425.

[10] A. Weir et al. Environ. Sci. Technol. 2012, 46(4), 2242.

[11] V. I. Shubayev, T. R. Pisanic, S. Jin. Adv. Drug Delivery Rev. 2009, 61, 467.

[12] J. R. McCarthy, R. Weissleder. Adv. Drug Delivery Rev. 2008, 60, 1241.

[13] J. W. W. Bulte, T. Douglas, B. Witwer, S. C. Zhang, E. Strable, B. K. Lewis, H. Zywicke, B. Miller, P. van Gelderen, B. M. Moskowitz, D. J. Duncan, J. A. Frank. Nat. Biotechnol. 2001, 19, 1141.

[14] E. Syková, P. Jendelová. Cell Death Differ. 2007, 14, 1336.

[15] O. Veiseh, J. W. Gunn, M. Zhang. Adv. Drug Delivery Rev. 2010, 62, 284.

[16] M. Chen, A. von Mikecz. Exp. Cell Res. 2005, 305(1), 51.

[17] M. Al-Rawi, S. Diabaté, C. Weiss. Arch. Toxicol. 2011, 85, 813.

[18] C. Uboldi, G. Giudetti, F. Broggi, D. Gilliland, J. Ponti, F. Rossi. Mutation Res. 2012, 745, 11.

[19] M. Xu, J. Li, H. Iwai, Q. Mei, D. Fujita, H. Su, H. Chen, N. Hanagata. Sci. Rep. 2012, 2, 406.

[20] T. Paunesku, S. Vogt, J. Maser, B. Lai, G. Woloschak. J. Cell. Biochem. 2006, 99, 1489.

[21] R. Ortega, C. Bresson, A. Fraysse, C. Sandre, G. Devès, C. Gombert, M. Tarabant, P. Bleuet, H. Seznec, A. Simionovici, P. Moretto, C. Moulin. Toxicol. Lett. 2009, 188(1), 2.

[22] C. J. Fahrni. Curr. Opin. Chem. Biol. 2007, 11, 121.

[23] E. Kosio, S. Bohic, H. Suhonen, R. Ortega, G. Devès, A. Carmona, F. March, J. F. Guillet, P. Cloetens. J. Struct. Biol. 2012, 177, 239.

[24] B. Kaulich, P. Thibault, A. Gianoncelli, M. Kiskinova. J. Phys. Condens. Matter 2011, 23, 083002.

[25] P. Marmorato, G. Ceccone, A. Gianoncelli, L. Pascolo, J. Ponti, F. Rossi, M. Salomé, B. Kaulich, M. Kiskinova. Toxicol. Lett. 2011, 207(2), 128.

[26] ELETTRA, Trieste, Italy, www.elettra.trieste.it/elettra-beamlines/twinmic.html

[27] S. Gyergyek, D. Makovec, A. Mertelj, M. Huski, M. Drofenik. Colloids Surf., A 2010, 366, 113.

[28] M. Makovec, S. Stanislav Campelj, M. Bele, U. Maver, M. Zorko, M. Drofenik, J. Jamnik, M. Gaberseck. Colloids Surf., A 2009, 334, 74.

[29] G. Baldi, D. Bonacchi, M. C. Franchini, D. Gentili, G. Lorenzi, A. Ricci, C. Ravagli. Langmuir 2007, 23(7), 4026.

[30] B. Kaulich, D. Bacescu, J. Susini, C. David, E. Di Fabrizio, G. R. Morrison, P. Charalambous, J. Thieme, T. Wilhein, J. Kovac, D. Cocco, M. Salome, O. Dhez, T. Weitkamp, S. Cabrini, D. Cojoc, A. Gianoncelli, U. Vogt, M. Podnar, M. Zangrando, M. Zacchigna, M. Kiskinova, Proc. 8th Int. Conf. X-ray Microsc., (IPAP,Tokyo), 2006, 7, 22.

[31] A. Gianoncelli, G. R. Morrison, B. Kaulich, D. Bacescu, J. Kovac. Appl. Phys. Lett. 2006, 89, 251117.

[32] A. Gianoncelli, B. Kaulich, R. Alberti, T. Klatka, A. Longoni, A. de Marco, A. Marcello, M. Kiskinova. Nucl. Instrum. Methods Phys. Res. A 2009, 608, 195.

[33] V. A. Sole, E. Papillon, M. Cotte, P. Walter, J. Susini. Spectrochim. Acta 2007, B 62(1), 63.

[34] M. Auffan, W. Achouak, J. Rose, M. A. Roncato, M. Chaneac, D. T. Waite, A. Masion, J. C. Woicik, M. R. Wiesner, J. Y. Botero. Environ. Sci. Toxicol. 2008, 42, 6730 . 